and duration of admissions during a corresponding period of equal length before starting therapy with long-acting phenothiazines. All patients received their first injection during a period of psychiatric relapse, but only 50 were admitted to hospital.

The follow up period ranged from 12 to 40 months, with an average of 24.8 months. All other necessary therapy remained constant throughout both retrospective and follow up periods. The Table summarizes our findings

\begin{tabular}{cr|c|c}
\hline & Admissions & $\begin{array}{c}\text { Duration } \\
\text { in Days }\end{array}$ \\
\hline $\begin{array}{cr}\text { Prior to Receiving } \\
\text { acting Fluphenazine }\end{array}$ & $\begin{array}{c}\text { Long- } \\
\text { After Long-acting } \\
\text { Fluphenazine }\end{array}$ & 241 & 10,048 \\
\hline
\end{tabular}

A more detailed analysis of the causes of the admissions during the follow up period is shown below.

\begin{tabular}{lr|c|c}
\hline Psychiatric relapse & 34 & Duration & 1022 days \\
\hline $\begin{array}{l}\text { Side effects } \\
\begin{array}{l}\text { Default in attendance for } \\
\text { injections with } \\
\text { psychiatric relapse }\end{array}\end{array}$ & 11 & $”$ & 70 days \\
\hline
\end{tabular}

In our series hospital admissions have been reduced from 241 to 50 , and in patient time by 8,713 days. We feel that our findings substantiate the claims made in your leading article.

You mention the lack of double blind controlled studies of long-acting fluphenazine. This may be caused by the risk that substitution of a placebo in this vulnerable group of patients is verv real and therefore poses ethical problems. We would like to bring to your attention two double blind controlled studies of fluphenazine enanthate. One is by Del Giudice et al. ${ }^{1}$ who divided 63 hosvitalized male schizophrenics into three groups on discharge. Group I (24 patients) received oral fluphenazine tablets. Group II (20 patients) received oral fluphenazine and were visited by a nurse every 15 days when a placebo iniection of secame oil was administered. Group III (19 patients) received oral placebo tablets and a visit from a nurse every 15 days when a fluphenazine enanthate injection was given. The efficacy of treatment was judged by the number of days out of hospital to the end of the follow up period or until readmission if any. The mean for Group I was 133 davs. Group II 164 days, and Group III 287 days. Statistical comparisons between Group I and Group II was not significant; between Group II and Grouv III was significant to the level of $p<0.001$; and between Group II and Group III was significant to the level of $\mathrm{p}<0.01$. Ravaris et al..$^{2}$ found 30 out of 34 hospitalized chronic schizophrenics developed regression with placebo.-We are, etc.,

St. Clement's Hospital,

JOHN DENHAM London E.3

L. ADAMSON

Associate Medical Director, E. R. Squibb and Sons Ltd Twickenham, Middx.

1 Del Guidice, et al., 7th Congress of the Collegium of International Neuro Psychopharmacologists. 1970, Ravaris, C.

American fournal of Psychiarry Brooks, G. H.

Representation of Regional Consultants

SIR,-The control of British medicine is moving rapidly from the hands of the individuals to central committees. The power of the Department of Health in monitoring and affecting our affairs is growing as is seen in the new proposals (see Supplement, 20 February, p. 47) for the Central Advisory Committee on Hospital Medical and Dental Staffing, which has an "overlord" control of hospital staff. In this an agglomeration of Department officials and our own inveterate politicians will decide the staffing structure.

We are now in the phase of a dwindling freedom to manage our own affairs in the periphery and must accept progressive central control. The regional consultants, comprising $70 \%$ of the total consultants,

hitherto more concerned with their clinical responsibilities, are now demanding greater representation in the central committees (Supplement, 4 July, p. 15).

The traditional control by the Londonbased consultants of the college and state committees is now seen as unacceptable. Active participation of consultants throughout the country is essential if their practical views are to be heard, and more to the point taken into account. The stampede of the Elephant and Castle to effect further control is now a major anxiety for British medicine.--I am, etc.,

J. J. Shipman

Letchworth, Herts

SIR,-The second report of the Royal ally (smoking is pollution); and it is bad College of Physicians re-emphasizes our medical psychology (the obligation of selfprofession's responsibilities in the matter of discipline is forgotten). Surely the time has health education about the hazards of smok- come for all postgraduate medical centres to ing. Unfortunately recent communications $s^{1-5}$ accept their anti-smoking and "clean air"

TABLE I

\begin{tabular}{c|c|c|c|c|c}
\hline $\begin{array}{c}\text { Date of } \\
\text { Circular }\end{array}$ & Circulation & $\begin{array}{c}\text { Replies } \\
\text { Received }\end{array}$ & $\begin{array}{c}\text { No Comment } \\
\text { or Comment } \\
\text { Incomplete }\end{array}$ & $\begin{array}{c}\text { Queationnaires } \\
\text { Analyeed }\end{array}$ & $\begin{array}{c}\text { Centres with } \\
\text { "No Smokting" } \\
\text { in Meetings }\end{array}$ \\
\hline $\begin{array}{l}\text { November } 1967 \\
\text { May 1969 }\end{array}$ & 228 & 170 & 24 & 146 & 19 \\
\hline
\end{tabular}

TABLE II

\begin{tabular}{|c|c|c|c|c|}
\hline Smoking in Meetings & $\ldots 127$ & \multirow[t]{2}{*}{ Smokers: Non-smokers at the various centres } & \multirow{2}{*}{$\begin{array}{l}\frac{1}{3} \text { or less } \\
\frac{1}{3}-\frac{1}{2} \\
\text { Over } \frac{1}{2} \\
\text { Unknown }\end{array}$} & \multirow{2}{*}{$\begin{array}{r}74 \\
25 \\
8 \\
20\end{array}$} \\
\hline $\begin{array}{l}\text { Smoking in the presence } 0 \\
\text { patients }\end{array}$ & $\ldots \quad 46$ & & & \\
\hline
\end{tabular}

have shown that medical students receive very inadequate anti-smoking instruction. Is it possible that our rapidly-improving postgraduate medical facilities are being used prophylactically to remedy the situation? To assess this possibility questionnaires had been circulated to all known postgraduate medical centres in England and Wales in November 1967, and again in May 1969. The quantitative responses are shown in Table I. Table II indicates the prevailing practices as recorded in November 1967 in 146 centres

Table III shows the low priority accorded to reconsideration by postgraduate medical centres of their policy (regarding smoking in meetings) during the 18 months between the two questionnaires.

TABLE III

Reconsideration: Smoking prohibited Reconsideration: Smoking permitted No Reconsideration: Smoking permitted

It is evident that during two-thirds of meetings at postgraduate medical centres two-thirds of the doctors did not smoke, yet four-fifths of the centres still permitted smoking. This paradoxical situation is trebly inappropriate: it is bad public relations educatively (the patients and lay staff get to know); it is bad public health environmentresponsibilities, and acknowledge that smoking is "sociable" only among consenting adults in private?-I am, etc.,

J. P. ANDERSON

Chest Clinic,

Musgrove Park Hospital, 1 Bynner. T. M.. Medical Students Attrtudes ToCurran. A. P. The Smoking Habits. of Medical
Students. Paper to Society for Social Medicine, Glassow, 1969 .

3 Arva, O. P., and Bennett, F. J., East African

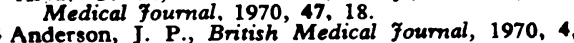
120. . J. P., British Medical foumal, 1970.
.

\section{Independent Contractors}

SIR, - Will someone explain how the profe;sion managed to discharge its duties during the postal strike without instruction from all those Government and other pamphlets which tell us how to do our job? Very well, I guess. It will be interesting to see the morbidity and mortality statistics during the next few months. - I am, etc.

Twickenham, Middx
Clive Shields 